\title{
Participatory data collection
}

\author{
Alta de Vos, ${ }^{1}$ Rika Preiser ${ }^{2}$ and Vanessa A. Masterson ${ }^{3}$ \\ ${ }^{1}$ DEPARTMENT OF ENVIRONMENTAL SCIENCE, RHODES UNIVERSITY, MAKHANDA, SOUTH AFRICA \\ ${ }^{2}$ CENTRE FOR SUSTAINABILITY TRANSITIONS, STELLENBOSCH UNIVERSITY, STELLENBOSCH, SOUTH AFRICA \\ ${ }^{3}$ STOCKHOLM RESILIENCE CENTRE, STOCKHOLM UNIVERSITY, STOCKHOLM, SWEDEN
}

\section{Key methods discussed in this chapter}

Participatory mapping (direct-to-digital participatory mapping, 3D-participatory mapping, participatory GIS), photovoice, transect walks, ranking exercises, focus group discussions, Venn diagrams, matrix scoring, ecograms, timelines, Q-methodology, community mapping, participatory videography, photo elicitation, seasonal calendars, participatory action research, participatory rural appraisal, participant observation, arts-based methods

\section{Connection to other chapters}

Participatory data collection methods can be used by many of the data analysis methods covered in this book, particularly those that require qualitative data. Indeed, the lines between data collection and analysis or modelling may be blurred at times. In particular, participatory modelling (Chapter 13), fuzzy cognitive mapping (Chapter 16), companion modelling (Chapter 12), as well as futures analysis (Chapter 10), scenario development (Chapter 11) and facilitated dialogues (Chapter 9) often involve the use of many of the methods described in this chapter, and can also be considered 'participatory data collection' processes in their own right. Many action research (Chapter 15), qualitative content analysis (Chapter 19), spatial mapping and analysis (Chapter 24), and livelihood and vulnerability analysis (Chapter 32) projects may also use the methods listed in this chapter.

\section{Introduction}

Social-ecological systems (SES) research acknowledges that how systems are framed depends on the observer, making it possible to have multiple valid descriptions or conceptualisations of a system (Preiser et al. 2018). These framings imply that, to understand how and why systems change, researchers often (but not always, see Hurlbert and Gupta 2015) need to employ participatory approaches and knowledge co-production. Knowledge co-production is the "collaborative process of bringing a plurality of knowledge sources and types together 


\begin{tabular}{|c|c|}
\hline DISCIPLINARY BACKGROUND & KNOWLEDGE TYPE \\
\hline $\begin{array}{l}\text { The methods in this chapter are derived } \\
\text { from or have most commonly been used in: } \\
\text { Sociology, Anthropology, Psychology, } \\
\text { Art, Development Studies }\end{array}$ & $\begin{array}{l}\text { The methods in this chapter are primarily } \\
\text { used to generate the following types of } \\
\text { knowledge: } \\
\text { - Descriptive } \\
\text { - Exploratory }\end{array}$ \\
\hline RESEARCH APPROACH & PURPOSE OF METHOD \\
\hline $\begin{array}{l}\text { The methods in this chapter originate } \\
\text { from or most commonly adopt the } \\
\text { following research approaches: } \\
\text { - Interpretive/subjective } \\
\text { - Collaborative/process }\end{array}$ & $\begin{array}{l}\text { The most common purposes of using the } \\
\text { methods in this chapter are: } \\
\text { - Data collection/generation } \\
\text { - Stakeholder engagement and } \\
\text { co-production }\end{array}$ \\
\hline TEMPORAL DIMENSION & SYSTEMIC FEATURES AND PROCESSES \\
\hline $\begin{array}{l}\text { The methods in this chapter are most } \\
\text { commonly applied to the following } \\
\text { temporal dimensions: } \\
\text { - Present (typically within the last } \\
5-10 \text { years) } \\
\text { - Recent past (post-1700s) } \\
\text { - Future }\end{array}$ & \multirow{3}{*}{$\begin{array}{l}\text { While most methods can do many } \\
\text { things, the methods in this chapter are } \\
\text { particularly good (i.e. go-to methods) for } \\
\text { addressing the following: } \\
\text { - SES components and linkages } \\
\text { - Social-ecological dependence } \\
\text { and impact } \\
\text { - Power relations } \\
\text { - Social learning }\end{array}$} \\
\hline SPATIAL DIMENSION & \\
\hline $\begin{array}{l}\text { The methods in this chapter are primarily } \\
\text { either or both: } \\
\text { - Non-spatial } \\
\text { - Explicitly spatial } \\
\text { The methods in this chapter are most } \\
\text { commonly applied at the following } \\
\text { spatial scales: } \\
\text { - Local } \\
\text { - Multiple places/sites around the world }\end{array}$ & \\
\hline
\end{tabular}


to address a defined problem and build an integrated or systems-oriented understanding of that problem' (Armitage et al. 2011, 996). As researchers and practitioners are increasingly acknowledging, local people hold important knowledge for addressing SES problems. They also have a stake in co-defining these problems in the first place, given that their livelihoods and well-being are most at risk of impact (Fischer and Eastwood 2016; $\mathrm{Nel}$ et al. 2016). Participatory approaches provide a mechanism to facilitate feedbacks and social learning (Stringer et al. 2006) and participatory data collection methods (participatory methods specifically used to generate or co-create data) are often used to establish shared interest and overlapping understanding across multiple knowledge domains (Roux et al. 2017). Participatory research focuses on a process of sequential actions, in which local people are part of, instead of the subject of, research processes (Cornwall and Jewkes 1995). Local knowledge and perspectives form the basis for research and planning (Cornwall and Jewkes 1995). What sets participatory research apart from non-participatory social research processes is its focus on navigating power imbalances between researchers and research participants, and among individuals in communities (Campbell 2002; Pain 2004; Van Riet and Boettiger 2009).

Participatory methods originate from many different fields in the social sciences, most notably development studies, anthropology, organisational studies, psychology and public health. Many of the methods discussed in this chapter also form part of well-established methodologies such as participatory rural appraisal (PRA), participatory learning and action (PLA), participatory action research (PAR) (see Chapter 13) and participatory mapping. All these methods have in common a focus on the co-production of knowledge with local knowledge- and stakeholders, prioritising the engagement process over the collection of data, and acknowledging and integrating multiple knowledge types.

Most participatory research emphasises 'knowledge for action' and requires a critical, reflective approach from the researcher. It demands an openness to see reality from the participants' point of view, and requires dynamic sharing of knowledge and perspectives between researchers and participants (Williams and Hardison 2013). Participatory methods often facilitate knowledge exchange and knowledge co-production among different knowledge systems, recognising that different knowledge systems are all internally valid and have their own strengths (Tengö et al. 2012, 2014). Tengö et al. (2012) identify the following essential principles for exchange across knowledge systems: trust, respect, reciprocity, equity, transparency, free, prior and informed consent. Williams and Hardison (2013) and Rambaldi et al. (2006) call for safeguards related to the rights of communities to their knowledge and knowledge ownership, including proper implementation of informed consent related to the sharing of their knowledge, and capacity building about the potential risks associated with sharing knowledge.

Many of the approaches used in social-ecological research today are linked to participatory rural appraisal and participatory learning and action approaches first adopted in the field of development in the 1960s and 1970s. Following a recognition that desired development outcomes would be achieved more effectively by working with the intended beneficiaries, researchers sought to modify existing social science methodologies in ways that could better incorporate affected people's local views. The early result was rapid rural appraisal, typically comprising a short visit by multiple experts who would set out to get a quick understanding of the system by interviewing local experts and consulting archival sources. This approach was heavily criticised, mostly because important decisions were 
being made based on limited, biased views. By the 1980s, participatory rural appraisal had developed (Chambers 1994) to emphasise more in-depth research engagement with communities and the inclusion of a greater diversity of voices within communities. Both participatory rural appraisal and participatory learning and action approaches have since been adopted in many different research fields, not only in appraisals and a rural setting.

The diversity of participatory methods has increased into the 21st century, with many innovations to better acknowledge and include the diverse needs and knowledge systems of local and indigenous people in co-defining problems (Smith et al. 2017), as well as inclusive ways of incorporating new technologies (e.g. participatory modelling, companion modelling, 3D-PGIS) (see Rambaldi et al. 2007; Barreteau et al. 2014).

\section{SES problems and questions}

Participatory data collection methods have not been specifically created to address SES questions, but many are inherently well suited to the SES domain and the incorporation of knowledge, preferences and values into decision-making about natural resources (Lynam et al. 2007). The richness and holistic nature of participatory data collection methods allow for the understanding of the nature of feedbacks between people and nature.

Participatory data collection methods are mostly employed at a local scale and are well suited to place-based research. These data collection methods are particularly useful in projects where the engagement process is important to the content and legitimacy of the outcome, and where mobilising local knowledge and perceptions is expedient and ethically responsible. When used responsibly, participatory methods can be useful tools to manage or dampen power dynamics (Reed 2008; Hill et al. 2012; Villamor et al. 2014), allowing voices that may otherwise have been silent or undervalued to be heard and legitimised (Stirling 2008).

Participatory methods are often used in research that concerns values and perceptions related to natural resources, their management and governance, and in projects that seek integration across knowledge systems. Certain participatory data collection methods, such as timelines, can be very useful for finding out how and why systems might change, particularly when combined with methods such as participatory modelling (see Chapter 13) or agentbased modelling (see Chapter 28).

Typical questions for participatory research could include the following:

- Where are important natural resources located, and how have they changed over time? (Levine and Feinholz 2015)

- How do different people within communities use natural resources differently? (Kalibo and Medley 2007)

- Where are priority areas for environmental restoration, and which restoration methods are most appropriate? (Cockburn et al. 2018; Weyer, Bezerra, and De Vos 2019)

- How and why have landscapes changed over time? (Sieber, Medeiros, and Albuquerque 2011)

- What are the potential impacts or unintended consequences of development interventions for different people within a community? (Mehryar et al. 2017)

- How do power and hierarchies influence people's access to ecosystem services? (Weyer, Bezerra, and De Vos 2019) 
- How can local visions of the future be used to inform natural resource management? (Palomo et al. 2011)

- How can local and indigenous knowledge inform local restoration or conservation actions? (Ramirez-Gomez, Brown, and Tjon Sie Fat 2013)

\section{Brief description of key methods}

Methods used in participatory data collection research all have in common a focus on facilitating data co-creation and navigating power relations among individuals in communities, and between researchers and communities. To facilitate the inclusion of multiple types of knowledge and knowledge systems and to engage a diversity of non-academic abilities and capacities across a variety of cultural contexts, many participatory data collection methods make use of visual methods (e.g. participatory photography, arts-based methods), whereas others employ modes of spatial and temporal mapping (e.g. community/participatory mapping, seasonal calendars, 3D-PGIS).

While not strictly a participatory method, it is important to also mention ethnographic research and participant observation here, as these tools for deep inductive and exploratory qualitative research are often used alongside participatory methods. Ethnographic research makes use of participant observation over long periods of time, research diaries and interviews to triangulate insights and produce rich and thick descriptions of phenomena. In this way ethnographic research approaches demand 'participation' of the researcher in the day-to-day life of study communities. For an introduction to ethnographic research, see LeCompte and Schensul (2010). For an example of how these methods have been applied to SES research, see Moerlein and Carothers (2012), Frey and Berkes (2014) and Laborde et al. (2016). Table 8.1 provides a summary of participatory data collection methods used in SES research.

Table 8.1 Summary of key participatory data collection methods used in SES research

\begin{tabular}{|c|c|c|}
\hline Method & Description & References \\
\hline $\begin{array}{l}\text { Participatory } \\
\text { photography }\end{array}$ & $\begin{array}{l}\text { Visual methods can reduce power imbalances } \\
\text { between researchers and the researched. One-on- } \\
\text { one interviews of photo elicitation are considered } \\
\text { participatory when they focus on photographs } \\
\text { taken by the interviewee, which allows participants } \\
\text { to retain control over what information they } \\
\text { share with researchers. Photovoice is a related but } \\
\text { distinct form of participatory visual storytelling, } \\
\text { where participants take their own photographs } \\
\text { related to a theme and share them in a group } \\
\text { setting. Photovoice facilitates learning processes by } \\
\text { capturing and sharing complex issues through a } \\
\text { visual narrative and allows for the co-construction } \\
\text { of knowledge through group participatory } \\
\text { processes of collective reflexivity and meaning- } \\
\text { making. There is often emphasis on advocacy and } \\
\text { the use of photographs to convey a message, e.g. } \\
\text { to decision-makers. }\end{array}$ & $\begin{array}{l}\text { Key introductory texts } \\
\text { Wang and Burris 1994, } \\
\text { 1997; } \\
\text { Harper 2002; } \\
\text { Pink } 2011 \\
\text { Applications to SES } \\
\text { Beilin 2005; } \\
\text { Mitchell and } \\
\text { De Lange 2011; } \\
\text { Berbés-Blázquez 2012; } \\
\text { Maclean and } \\
\text { Woodward 2013; } \\
\text { Kong et al. 2015; } \\
\text { Robinson et al. 2016; } \\
\text { Masterson et al. 2018 }\end{array}$ \\
\hline
\end{tabular}

(Continued) 
Alta de Vos et al.

Table 8.1 (Continued)

\begin{tabular}{|c|c|c|}
\hline Method & Description & References \\
\hline $\begin{array}{l}\text { Timelines, } \\
\text { matrices, Venn } \\
\text { diagrams, } \\
\text { ranking exercises }\end{array}$ & $\begin{array}{l}\text { These tools are often used in a focus group setting } \\
\text { and are considered 'classic' participatory rural } \\
\text { appraisal techniques. The timeline technique } \\
\text { comprises a drawn line, on which participants } \\
\text { highlight key events, changes or visions of the } \\
\text { future. Matrix-scoring exercises are often used } \\
\text { to discern cause and effect. Venn diagrams are } \\
\text { used to highlight key social interactions, whereas } \\
\text { ranking exercises involve prioritising resources, } \\
\text { livelihoods and other elements in order of } \\
\text { importance. }\end{array}$ & $\begin{array}{l}\text { Key introductory texts } \\
\text { Newing et al. 2011; } \\
\text { Schreckenberg et al. } 2016 \\
\text { Applications to SES } \\
\text { Bunce et al. 2010; } \\
\text { Malinga et al. 2013; } \\
\text { Sinare, Gordon, and Enfors- } \\
\text { Kautsky 2016; } \\
\text { Masterson et al. } 2017\end{array}$ \\
\hline Transect walks & $\begin{array}{l}\text { A transect walk is a systematic walk by the research } \\
\text { team and community members along a defined } \\
\text { path (transect) across the community/project area } \\
\text { together with community members to explore } \\
\text { certain SES contexts and conditions by observing, } \\
\text { asking and listening. The result is a transect map. } \\
\text { Transect walks are usually conducted during the } \\
\text { early phase of fieldwork. }\end{array}$ & $\begin{array}{l}\text { Key introductory texts } \\
\text { Newing et al. 2011; } \\
\text { Schreckenberg et al. } 2016 \\
\text { Applications to SES } \\
\text { Kalibo and Medley 2007; } \\
\text { Malmborg et al. } 2018\end{array}$ \\
\hline $\begin{array}{l}\text { Focus group } \\
\text { discussions }\end{array}$ & $\begin{array}{l}\text { Many of the other participatory methods } \\
\text { mentioned in this table can happen in a focus } \\
\text { group setting, but focus group discussions do not } \\
\text { necessarily have to involve particular exercises. } \\
\text { They can simply be group discussion on how } \\
\text { people relate to the environment and how they } \\
\text { adapt, with an emphasis on understanding their } \\
\text { views and values. }\end{array}$ & $\begin{array}{l}\text { Key introductory text } \\
\text { Newing et al. } 2011 \\
\text { Applications to SES } \\
\text { Nyirenda and Drive 2015; } \\
\text { Sinare, Gordon, and Enfors- } \\
\text { Kautsky 2016; } \\
\text { Sylvester, Segura, and } \\
\text { Davidson-Hunt } 2016\end{array}$ \\
\hline Q-methodology & $\begin{array}{l}\text { Q-methodology originated in the field of } \\
\text { psychology and is useful when researchers wish } \\
\text { to understand and describe subjectivity. Many } \\
\text { variants of Q-methodology require participants } \\
\text { to sort statements on a pre-configured grid, } \\
\text { according to their preferences, followed by group } \\
\text { discussion. }\end{array}$ & $\begin{array}{l}\text { Key introductory texts } \\
\text { Newing et al. 2011; } \\
\text { Watts and Stenner } 2012 \\
\text { Applications to SES } \\
\text { Milcu et al. 2014; } \\
\text { Forrester et al. 2015; } \\
\text { Murray, D'Anna, and } \\
\text { MacDonald 2016; } \\
\text { West, Cairns, and } \\
\text { Schultz 2016; } \\
\text { Armatas, Venn, and } \\
\text { Watson 2017; } \\
\text { Rust 2017 }\end{array}$ \\
\hline $\begin{array}{l}\text { Seasonal } \\
\text { calendars }\end{array}$ & $\begin{array}{l}\text { Seasonal calendars are a tool to map seasonal } \\
\text { changes in resources, events, institutions and } \\
\text { customs, usually in a public, participatory setting. }\end{array}$ & $\begin{array}{l}\text { Key introductory texts } \\
\text { Newing et al. 2011; } \\
\text { Schreckenberg et al. } 2016 \\
\text { Applications to SES } \\
\text { Aburto et al. } 2013\end{array}$ \\
\hline
\end{tabular}




\begin{tabular}{|c|c|c|}
\hline Method & Description & References \\
\hline $\begin{array}{l}\text { Community } \\
\text { mapping }\end{array}$ & $\begin{array}{l}\text { Community mapping concerns the mapping of } \\
\text { resources or important places in relation to one } \\
\text { another. }\end{array}$ & $\begin{array}{l}\text { Key introductory text } \\
\text { Schreckenberg et al. } 2016 \\
\text { Applications to SES } \\
\text { Belay 2012; } \\
\text { Villamor et al. } 2014\end{array}$ \\
\hline Participatory GIS & $\begin{array}{l}\text { Participatory geographic information systems } \\
\text { (GIS) differ from community mapping primarily on } \\
\text { account of the accuracy of spatial representation. } \\
\text { Participatory GIS involves either the use of digitised } \\
\text { maps in a GIS, or the use of virtual earth and } \\
\text { mapping technologies (most commonly Google } \\
\text { Earth) to map information such as preferences } \\
\text { or use directly onto a digital platform. 3D-PGIS } \\
\text { requires the construction of a 3D model of the } \\
\text { landscape by community members, typically out } \\
\text { of papier-mâché, ribbons and pins. The focus in } \\
\text { 3D-PGIS is on the process of building the model, } \\
\text { and ownership of the resultant data and model } \\
\text { belongs to the community who created it. }\end{array}$ & $\begin{array}{l}\text { Key introductory texts } \\
\text { Rambaldi et al. 2007; } \\
\text { Bryan 2015; } \\
\text { Brown } 2017 \\
\text { Applications to SES } \\
\text { Rambaldi et al. 2007; } \\
\text { Raymond et al. 2009; } \\
\text { Olson, Hackett, and } \\
\text { DeRoy 2016; } \\
\text { Ramirez-Gomez et al. 2017; } \\
\text { Samuelsson et al. } 2018\end{array}$ \\
\hline $\begin{array}{l}\text { Arts-based } \\
\text { methods }\end{array}$ & $\begin{array}{l}\text { Arts-based methods refer to a broad group of } \\
\text { participatory methods that specifically make use } \\
\text { of at least one of a diversity of art genres (e.g. } \\
\text { performance, writing, photography, mosaicking, } \\
\text { collage, sculpture, painting) in collecting data. The } \\
\text { co-creation of artistic pieces with participants may } \\
\text { elicit knowledge, values and emotions. Creating } \\
\text { art and performance pieces together can facilitate } \\
\text { discussion on a shared platform that is more } \\
\text { familiar to many, and even produce a 'boundary } \\
\text { object' which might be understood differently by } \\
\text { different participants but initiates discussion. Many } \\
\text { of these methods, e.g. applied theatre, are devised } \\
\text { in close collaboration with the communities they } \\
\text { target and are often directed at social change. }\end{array}$ & $\begin{array}{l}\text { Key introductory texts } \\
\text { Liamputtong and Rumbold } \\
\text { 2008; } \\
\text { Bagnoli 2009; } \\
\text { Heras and Tàbara } 2014 \\
\text { Applications to SES } \\
\text { Walker 2012; } \\
\text { Lemelin et al. 2013; } \\
\text { Heras and Tàbara 2014; } \\
\text { Brown et al. 2017; } \\
\text { Johansson and Isgren } 2017\end{array}$ \\
\hline $\begin{array}{l}\text { Participant } \\
\text { observation and } \\
\text { ethnographic } \\
\text { research }\end{array}$ & $\begin{array}{l}\text { Participant observation is not participatory in } \\
\text { the same way as other methods in this chapter, } \\
\text { in that it does not require participation from the } \\
\text { research participants as such. Rather, it involves the } \\
\text { researchers immersing themselves in community } \\
\text { life and in a sense becoming participants in the } \\
\text { community, thus blurring the lines between } \\
\text { researcher and research 'subject'. } \\
\text { Ethnography is a type of qualitative research that } \\
\text { involves immersing yourself in a particular } \\
\text { community or organisation to observe their } \\
\text { behaviour and interactions up close. Ethnography is } \\
\text { a flexible research method that allows one to gain } \\
\text { a deep understanding of a group's shared culture, } \\
\text { conventions and social dynamics. However, it also } \\
\text { involves some practical and ethical challenges. }\end{array}$ & $\begin{array}{l}\text { Key introductory text } \\
\text { LeCompte and } \\
\text { Schensul } 2010 \\
\text { Applications to SES } \\
\text { Moerlein and } \\
\text { Carothers 2012; } \\
\text { Frey and Berkes 2014; } \\
\text { Laborde et al. } 2016\end{array}$ \\
\hline
\end{tabular}




\section{Limitations}

Participatory data collection explicitly requires interaction with people. The level of engagement and trust required in these exercises can carry substantial ethical risks, which need to be considered prior to commencement. These ethical risks particularly concern unmet expectations and equality of voice. Many kinds of engagements may count as 'participatory' and it may not always be clear to research participants what is expected of them, or what the research might entail. This may lead to the generation of mistrust between researchers and research participants when expectations are not met. It is also important to consider which methods are appropriate for a setting and the cultural context and contemporary issues faced by communities. Researchers need to be cognisant of the power of participatory methods (especially those with roots in advocacy such as forum theatre or photovoice) for learning and illuminating issues that inspire a desire for change. They should therefore be responsible when initiating dialogues with communities (Wang and Burris 1994; Belay 2012).

How problems are framed has important consequences for achieving or undermining justice in participatory research (Stirling 2008; Scoones et al. 2018). It can be easy to exclude the most vulnerable voices in participatory research, which may also result in shallow depictions of the local reality (Schreckenberg et al. 2016). Without careful consideration of who are included in participatory research and in what way, participatory methods may perpetuate existing gender and cultural biases.

Participatory methods are also associated with more practical and logistical limitations. These methods may be biased in favour of areas and people who are easily accessible and who have the capability to participate in the research activities, and areas that are more similar to the cultural norms and language of the researcher (Campbell 2002). Accessibility to participants, along with other elements of participatory research, may be sensitive to seasonality (Schreckenberg et al. 2016). Accounting for accessibility, however, has significant implications for the time and financial resources needed to conduct this kind of research. In addition to the time required for the researchers to get to participants, participatory activities can place a large demand on participants' time (Campbell 2002; Pain 2004; Schreckenberg et al. 2016; Brown and Kyttä 2018).

Since participatory data collection methods always concern the co-production of knowledge, the questions of who the data belong to and how the data should be stored and shared can be difficult ones to answer. This is particularly true in studies and projects that make use of participatory mapping techniques and produce maps as an outcome (Rambaldi et al. 2006), or visual ethnography methods that produce photographs (Pink 2011).

As with other social research, it is key that free, prior and informed consent is sought from participants. The research protocol must be approved by a research ethics council before research begins. Different countries and institutions have different procedures and requirements that may apply to research with or on vulnerable groups, so it is critical that researchers consult their university administration or ethics office before embarking on research of this nature. It is also important to consult specific codes of research ethics drawn up by indigenous people (e.g. Callaway 2017), where these exist.

\section{Resource implications}

Many participatory mapping methods require very little in the way of hardware or software, relying on flipcharts and markers, or even drawings in the sand. Voice recorders are often the only hardware that accompanies researchers in the field. Some participatory methods require 
specific equipment. Photovoice, for example, requires the use of cameras or smartphones and the opportunity to print or project photographs. Methods such as 3D-PGIS require constructing material, such as papier-mâché, for building models. Mapping with virtual globes (such as Google Earth, which is free to download) requires a computer, pointer, projector and screen. Although an Internet connection is desirable, it is not critical.

Participatory GIS requires basic GIS knowledge, and researchers administrating this method should be familiar with making maps. Digitising hard-copy maps and creating maps may require the use of ESRI's ArcGIS or QGIS. Analysing participatory data may require significantly more technical skill and knowledge of statistical packages, GIS tools, tools and platforms to conduct thematic analysis, including qualitative computer packages such as Atlas.ti or InVivo (see Chapter 19).

Whereas materials to run participatory processes may not be very expensive, participatory methods are nevertheless resource intensive. Getting participants involved in research and using mapping software or cameras, for example, mean the researcher has an added responsibility of managing and negotiating the type of capacity, skills and training people would need to engage in the research on an equitable basis. Projects that make use of participatory methods can be very expensive, as a project should be able to afford the cost of interpreters or translators, skilled facilitators and drivers as well as accessing sometimes very inaccessible locations. Some field sites may require the use of specific vehicles and specialist drivers, or the need for extra security. Setting up participatory processes can be very time consuming and may also require the use of community resources. Time is one of the most important resource considerations for participatory research, especially if there are multiple iterations of a process.

\section{New directions}

Participatory data collection methods are now widely used in SES research. Participatory mapping has already benefited from the introduction of technology, particularly the use of virtual globes like Google Earth. The more recent development of virtual reality promises to deepen the experience of participatory data collection. Platforms such as Ushahidi, Kobo Collect and Open Data Kit have greatly improved the affordability and ease of participatory monitoring. These technologies potentially allow for participatory mapping methods to be used over larger spatial extents, widening the degree to which different people may 'participate'. However, they also open up new ethical concerns around data privacy and ownership.

In recent years, participatory data collection methods have been adapted and applied increasingly in approaches that go beyond 'participation' towards the co-production of knowledge (e.g. Tengö et al. 2014, 2017; Scoones et al. 2018) and achieving greater social and epistemic justice (Roux et al. 2017). Notably, the multiple evidence base approach (Tengö et al. 2014, 2017) emphasises the self-representation of knowledge and perspectives, and the internal validation of knowledge systems. Similarly, the STEP centre's pathways approach (Leach, Scoones, and Stirling 2010) emphasises the importance of research pathways that use methods and methodologies in a way that favours the rights, interests and values of marginalised and excluded people.

Participatory methods are increasingly being used in action research focused on transformation (Chapter 15). This includes processes described elsewhere in this book, such as facilitated dialogues (Chapter 9) and scenario development (Chapter 11). Arts-based methods are also increasingly being incorporated in participatory data collection processes as a way of deepening conversations with research participants towards learning and transformation (Bennett et al. 2016). 


\section{Case study 8.1: Understanding the role of sense of place in landscape dynamics in South Africa}

Masterson, Mahajan and Tengö (2018) sought to understand the ways in which people in the former Transkei, in the Eastern Cape province of South Africa, perceive social and ecological changes in the landscape over time and how these changes have influenced their well-being. The former Transkei homeland (a homeland refers to an area established during the apartheid era to which black South Africans were forcibly removed under the policy of separate development) was historically a place of small-scale farming, supported by remittance wages from migrant family members. However, the area has witnessed a long-term decline in cultivation and animal husbandry coupled with bush encroachment. Today, the region remains underdeveloped with high rates of outmigration to urban areas and a heavy reliance on social welfare grants.

The research team (see Masterson 2016; Masterson, Mahajan, and Tengö 2018) explored rural residents' experiences of and responses to declining subsistence agriculture and continued labour migration, through a lens of sense of place. To gain a deep understanding of local perspectives on well-being and to overcome cultural differences and language barriers, the researchers settled on photovoice as their main methodology.



Figure 8.1 The kraal (@ M. Bili 2013) 'That is the kraal [cattle byre], but you can see there inside, there's no manure, which clearly shows that they have no livestock there at that home. But even if you haven't got livestock, it's important to have a kraal at home, because that is a place that you need when you perform your rituals. As people we have different perspectives. Some people are in the cities and have jobs and earn much money. For those they see having livestock as something unimportant.' - M. Bili, photovoice exercise, 2013, Gqunqe, South Africa 
In this study, four demographic groups of between three and six individuals used small digital cameras to capture aspects of the local landscape that were important to them. Each group convened multiple times (between four and six times) over five weeks. After basic training in visual literacy, individuals in the groups took photographs that represented their lived experience in the rural village landscape. Each participant selected the most important images, which were printed. These photographs were then either narrated or captioned by the photographers. This process formed the basis of in-depth discussions in the group, all of which were recorded with the free, prior and informed consent of the participants. All four groups chose to make a poster based on an issue that the group had identified, and displayed this in public places around the villages. Photographs, captions and translated transcriptions of the discussions formed the data for a thematic qualitative analysis by the researchers.

In this case study, photovoice provided an inventory of human-nature relationships highlighting the diversity of ways in which ecosystems influenced people's well-being, despite a low economic reliance on these resources. Participants' photographs illustrated the often hidden cultural and non-monetised connections that people have to an agricultural lifestyle. This was important for maintaining subjective aspects

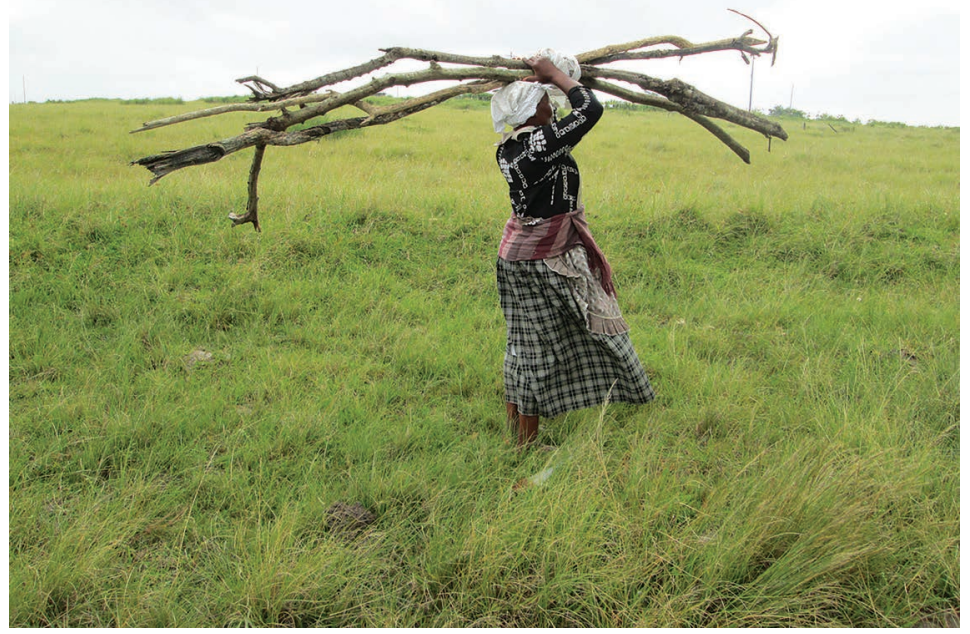

Figure 8.2 Collecting firewood (๑ N. Zibonele 2013) 'This is our way of living. You have to go to the forest and come back with a headbundle of firewood to use at home. That's where women go to get firewood. It's good and bad to have forests. There in the forest as umama going to collect firewood, you can meet a rapist hiding there. There are times when you will feel happy in the forest - when it's very hot and you enjoy the shade of the trees and rest there. But to be alone in the forest is not safe.' - N. Zibonele, photovoice exercise, 2013, Nobuswana, South Africa 
of well-being and was a strong motivator to continue farming practices despite the changing livelihood portfolios of local people (Figure 8.1).

Photographs and discussions also pointed to the role of nature in the well-being of different groups in the community. This was particularly because the method of taking photographs was able to engage individuals who might be overlooked in focus groups or written surveys. Young women, for example, do not have many opportunities to represent themselves in this patriarchal cultural context, but through photovoice they could represent their concerns and be the experts on their lived experience, illustrating gender-specific perspectives on the landscape that affected, for example, women's sense of safety (Figure 8.2).

Through their photographs and discussions, participants also communicated their knowledge of the dynamics of the SES. Photographs of landscape elements demonstrated their culturally contingent sense-making of the complexity of the interacting drivers of field abandonment, bush encroachment and migration. Most importantly, photovoice encouraged mobilisation of tacit knowledge and reflection on these insights through group discussion.

\section{Key readings}

Lynam, T., W. de Jong, D. Sheil, T. Kusumanto, and K. Evans. 2007. 'A Review of Tools for Incorporating Community Knowledge, Preferences, and Values into Decision Making in Natural Resources Management.' Ecology and Society 12(1): 5.

Newing, H. 2010. Conducting Research in Conservation: Social Science Methods and Practice. Abingdon: Routledge.

Rambaldi, G., R. Chambers, M. McCall, and J. Fox. 2006. 'Practical Ethics for PGIS Practitioners, Facilitators, Technology Intermediaries and Researchers.' Participatory Learning and Action 54(1): 106-113.

Schreckenberg, K., C.A. Torres-Vitolas, S. Willcock, C. Shackleton, C.A. Harvey, and D. Kafumbata. 2016. 'Participatory Data Collection for Ecosystem Services Research: A Practitioner's Manual.' ESPA Working Paper Series 3.

\section{Acknowledgements}

The authors would like to thank the participant photographers in the photovoice study for their generous hospitality and willingness to co-create this research. They are also grateful to Faith Mabusela for assistance in the field. Alta de Vos is supported by a Rhodes Council Grant. Rika Preiser is funded by the USAID Resilient Waters Program (contract no. 72067418C00007). Vanessa Masterson acknowledges support from the Swedish Research Council (VR 2017-06337).

\section{References}

Aburto, J., G. Gallardo, W. Stotz, C. Cerda, C. Mondaca-Schachermayer, and K. Vera. 2013. 'Territorial User Rights for Artisanal Fisheries in Chile - Intended and Unintended Outcomes.' Ocean and Coastal Management 71: 284-295.

Armatas, C., T. Venn, and A. Watson. 2017. 'Understanding Social-Ecological Vulnerability with Q-Methodology: A Case Study of Water-based Ecosystem Services in Wyoming, USA.' Sustainability Science 12(1): 105-121. 
Armitage, D., F. Berkes, A. Dale, E. Kocho-Schellenberg, and E. Patton. 2011. 'Co-management and the Co-Production of Knowledge: Learning to Adapt in Canada's Arctic.' Global Environmental Change 21(3): 995-1004.

Bagnoli, A. 2009. 'Beyond the Standard Interview: The Use of Graphic Elicitation and Arts-based Methods.' Qualitative Research 9(5): 547-570.

Barreteau, O., F. Bousquet, M. Étienne, V. Souchère, and P. d’Aquino. 2014. 'Companion Modelling: A Method of Adaptive and Participatory Research.' In Companion Modelling, edited by M. Étienne, 13-40. Dordrecht: Springer.

Beilin, R. 2005. 'Photo-elicitation and the Agricultural Landscape: 'Seeing' and 'Telling' about Farming, Community and Place.' Visual Studies 20(1): 56-68.

Belay, M. 2012. 'Participatory Mapping, Learning and Change in the Context of Biocultural Diversity and Resilience.' PhD diss., Rhodes University.

Bennett, N.J., J. Blythe, S. Tyler, and N.C. Ban. 2016. 'Communities and Change in the Anthropocene: Understanding Social-Ecological Vulnerability and Planning Adaptations to Multiple Interacting Exposures.' Regional Environmental Change 16(4): 907-926.

Berbés-Blázquez, M. 2012. 'A Participatory Assessment of Ecosystem Services and Human Wellbeing in Rural Costa Rica Using Photo-voice.' Environmental Management 49(4): 862-875.

Brown, G. 2017. 'A Review of Sampling Effects and Response Bias in Internet Participatory Mapping (PPGIS/PGIS/VGI).' Transactions in GIS 21(1): 39-56.

Brown, G., and M. Kyttä. 2018. 'Key Issues and Priorities in Participatory Mapping: Toward Integration or Increased Specialization?' Applied Geography 95: 1-8.

Brown, K., N. Eernstman, A.R. Huke, and N. Reding. 2017. 'The Drama of Resilience: Learning, Doing, and Sharing for Sustainability.' Ecology and Society 22(2): 8.

Bryan, J. 2015. 'Participatory Mapping.' In The Routledge Handbook of Political Ecology, edited by T.A. Perreault, G. Bridge, and J. McCarthy, 249-262. New York: Routledge.

Callaway, E. 2017. 'South Africa's San People Issue Ethics Code to Scientists.' Nature News 543(7646): $475-476$.

Campbell, J. 2002. 'A Critical Appraisal of Participatory Methods in Development Research.' International Journal of Social Research Methodology 5(1): 19-29.

Chambers, R. 1994. 'The Origins and Practice of Participatory Rural Appraisal.' World Development 22(7): 953-969.

Cockburn, J., C. Palmer, H. Biggs, and E. Rosenberg. 2018. 'Navigating Multiple Tensions for Engaged Praxis in a Complex Social-Ecological System.' Land 7(4): 129.

Cornwall, A., and R. Jewkes. 1995. 'What is Participatory Research?' Social Science and Medicine 41(12): 1667-1676.

Fischer, A., and A. Eastwood. 2016. 'Coproduction of Ecosystem Services as Human-Nature Interactions - An Analytical Framework.' Land Use Policy 52: 41-50.

Forrester, J., B. Cook, L. Bracken, S. Cinderby, and A. Donaldson. 2015. 'Combining Participatory Mapping with Q-Methodology to Map Stakeholder Perceptions of Complex Environmental Problems.' Applied Geography 56: 199-208.

Frey, J., and F. Berkes. 2014. 'Can Partnerships and Community-based Conservation Reverse the Decline of Coral Reef Social-Ecological Systems?' International Journal of the Commons 8(1): 26-46.

Harper, D. 2002. 'Talking about Pictures: A Case for Photo Elicitation.' Visual Studies 17(1): 13-26.

Heras, M., and J. D. Tàbara. 2014. 'Let's Play Transformations! Performative Methods for Sustainability.' Sustainability Science 9(3): 379-398.

Hill, R., C. Grant, M. George, C.J. Robinson, S. Jackson, and N. Abel. 2012. 'A Typology of Indigenous Engagement in Australian Environmental Management: Implications for Knowledge Integration and Social-Ecological System Sustainability.' Ecology and Society 17(1): 23.

Hurlbert, M., and J. Gupta. 2015. 'The Split Ladder of Participation: A Diagnostic, Strategic, and Evaluation Tool to Assess When Participation is Necessary.' Environmental Science and Policy 50: 100-113.

Johansson, E.L., and E. Isgren. 2017. 'Local Perceptions of Land-use Change: Using Participatory Art to Reveal Direct and Indirect Socioenvironmental Effects of Land Acquisitions in Kilombero Valley, Tanzania.' Ecology and Society 22(1): 3.

Kalibo, H.W., and K.E. Medley. 2007. 'Participatory Resource Mapping for Adaptive Collaborative Management at Mount Kasigau, Kenya.' Landscape and Urban Planning 82(3): 145-158.

Kong, T.M., K. Kellner, D.E. Austin, Y. Els, and B.J. Orr. 2015. 'Enhancing Participatory Evaluation of Land Management through Photo Elicitation and Photovoice.' Society and Natural Resources 28(2): 212-229. 
Laborde, S., A. Fernández, S.C. Phang, I.M. Hamilton, N. Henry, H.C. Jung, A. Mahamat et al. 2016. 'Social-Ecological Feedbacks Lead to Unsustainable Lock-in in an Inland Fishery.' Global Environmental Change 41: 13-25.

Leach, M., I. Scoones, and A. Stirling. 2010. 'Governing Epidemics in an Age of Complexity: Narratives, Politics and Pathways to Sustainability.' Global Environmental Change 20(3): 369-377.

LeCompte, M., and J. Schensul. 2010. Designing and Conducting Ethnographic Research: An Introduction (2nd ed). New York: Rowman Altamira.

Lemelin, R.H., E.C. Wiersma, L. Trapper, R. Kapashesit, M.S. Beaulieu, and M. Dowsley. 2013. 'A Dialogue and Reflection on Photohistory: Engaging Indigenous Communities in Research through Visual Analysis.' Action Research 11(1): 92-107.

Levine, A. S., and C.L. Feinholz. 2015. 'Participatory GIS to Inform Coral Reef Ecosystem Management: Mapping Human Coastal and Ocean Uses in Hawaii.' Applied Geography 59: 60-69.

Liamputtong, P., and J. Rumbold. 2008. Knowing Differently: Arts-based and Collaborative Research Methods. New York: Nova Science Publishers.

Lynam, T., W. de Jong, D. Sheil, T. Kusumanto, and K. Evans. 2007. 'A Review of Tools for Incorporating Community Knowledge, Preferences, and Values into Decision Making in Natural Resources Management.' Ecology and Society 12(1): 5.

Maclean, K., and E. Woodward. 2013. 'Photovoice Evaluated: An Appropriate Visual Methodology for Aboriginal Water Resource Research.' Geographical Research 51(1): 94-105.

Malmborg, K., H. Sinare, E. Enfors-Kautsky, I. Ouedraogo, and L.J. Gordon. 2018. 'Mapping Regional Livelihood Benefits from Local Ecosystem Services Assessments in Rural Sahel.' PLoS ONE 13(2): e0192019.

Masterson, V.A. 2016. 'Sense of Place and Culture in the Landscape of Home: Understanding Social-Ecological Dynamics on the Wild Coast, South Africa.' PhD diss., Stockholm University.

Masterson, V., S. Mahajan, and M. Tengö. 2018. 'Photovoice for Mobilizing Insights on Complex Social-Ecological Dynamics - Case Studies from Kenya and South Africa.' Ecology and Society 23(3): 13 .

Mehryar, S., R. Sliuzas, A. Sharifi, D. Reckien, and M. van Maarseveen. 2017. 'A Structured Participatory Method to Support Policy Option Analysis in a Social-Ecological System.' Journal of Environmental Management 197: 360-372.

Milcu, A.I., K. Sherren, J. Hanspach, D. Abson, and J. Fischer. 2014. 'Navigating Conflicting Landscape Aspirations: Application of a Photo-Based Q-Method in Transylvania (Central Romania).' Land Use Policy 41: 408-422.

Mitchell, C., and N. de Lange. 2011. 'Community-based Participatory Video and Social Action in Rural South Africa.' In The SAGE Handbook of Visual Research Methods, edited by E. Margolis and L. Pauwels, 171-183. Los Angeles: Sage Publications.

Moerlein, K.J., and C. Carothers. 2012. 'Total Environment of Change: Impacts of Climate Change and Social Transitions on Subsistence Fisheries in Northwest Alaska.' Ecology and Society 17(1): 10.

Murray, G., L. D’Anna, and P. MacDonald. 2016. 'Measuring What We Value: The Utility of Mixed Methods Approaches for Incorporating Values into Marine Social-Ecological System Management.' Marine Policy 73: 61-68.

Nel, J.L., D.J. Roux, A. Driver, L. Hill, A.C. Maherry, K. Snaddon, C.R. Petersen, L.B. Smith-Adao, H. van Deventer, and B. Reyers. 2016. 'Knowledge Co-production and Boundary Work to Promote Implementation of Conservation Plans.' Conservation Biology 30(1): 176-188.

Newing, H., C.M. Eagle, R.K. Puri, and C. W. Watson. 2011. Conducting Research in Conservation: Social Science Methods and Practice. Abingdon: Routledge.

Nyirenda, V.R., and J. Drive. 2015. 'Role of Relational Social Capital in Transforming Conservation Inequalities and Conflicts to Sustainable Solutions in Developing Countries Chansa Chomba.' International Journal of Sustainable Development 18(3): 229-246.

Olson, R., J. Hackett, and S. DeRoy. 2016. 'Mapping the Digital Terrain: Towards Indigenous Geographic Information and Spatial Data Quality Indicators for Indigenous Knowledge and Traditional Land-use Data Collection.' The Cartographic Journal 53(4): 348-355.

Pain, R. 2004. 'Social Geography: Participatory Research.' Progress in Human Geography 28(5): 652-663.

Palomo, I., B. Martín-López, C. López-Santiago, and C. Montes. 2011. 'Participatory Scenario Planning for Protected Areas Management under the Ecosystem Services Framework: The Doñana Social-Ecological System in Southwestern Spain.' Ecology and Society 16(1): 23. 
Pink, S. 2011. 'Images, Senses and Applications: Engaging Visual Anthropology.' Visual Anthropology 24(5): 437-454.

Preiser, R., R. Biggs, A. de Vos, and C. Folke. 2018. 'Social-Ecological Systems as Complex Adaptive Systems: Organizing Principles for Advancing Research Methods and Approaches.' Ecology and Society 23(4): 46.

Rambaldi, G., R. Chambers, M. McCall, and J. Fox. 2006. 'Practical Ethics for PGIS Practitioners, Facilitators, Technology Intermediaries and Researchers.' Participatory Learning and Action 54(14): 106-113.

Rambaldi, G., J. Muchemi, N. Crawhall, and L. Monaci. 2007. 'Through the Eyes of Hunter-Gatherers: Participatory 3D Modelling among Ogiek Indigenous Peoples in Kenya.' Information Development 23(2-3): 113-128.

Ramirez-Gomez, S.O.I, G. Brown, and A. Tjon Sie Fat. 2013. 'Participatory Mapping with Indigenous Communities for Conservation: Challenges and Lessons from Suriname.' The Electronic Journal of Information Systems in Developing Countries 58(1): 1-22.

Ramirez-Gomez, S.O.I., P. Verweij, L. Best, R. van Kanten, G. Rambaldi, and R. Zagt. 2017. 'Participatory 3D Modelling as a Socially Engaging and User-useful Approach in Ecosystem Service Assessments among Marginalized Communities.' Applied Geography 83: 63-77.

Raymond, C.M., B.A. Bryan, D.H. MacDonald, A. Cast, S. Strathearn, A. Grandgirard, and T. Kalivas. 2009. 'Mapping Community Values for Natural Capital and Ecosystem Services.' Ecological Economics 68(5): 1301-1315.

Reed, M.S. 2008. 'Stakeholder Participation for Environmental Management: A Literature Review.' Biological Conservation 141(10): 2417-2431.

Robinson, C.J., K. Maclean, R. Hill, E. Bock, and P. Rist. 2016. 'Participatory Mapping to Negotiate Indigenous Knowledge used to Assess Environmental Risk.' Sustainability Science 11(1): 115-126.

Roux, D.J., J.L. Nel, G. Cundill, P. O’Farrell, and C. Fabricius. 2017. 'Transdisciplinary Research for Systemic Change: Who to Learn With, What to Learn About and How to Learn.' Sustainability Science 12(5): 711-726.

Rust, N.A. 2017. 'Can Stakeholders Agree on How to Reduce Human-Carnivore Conflict on Namibian Livestock Farms? A Novel Q-Methodology and Delphi Exercise.' Oryx 51(2): 339-346.

Samuelsson, K., M. Giusti, G.D. Peterson, A. Legeby, S.A. Brandt, and S. Barthel. 2018. 'Impact of Environment on People's Everyday Experiences in Stockholm.' Landscape and Urban Planning 171: 7-17.

Schreckenberg, K., C.A. Torres-Vitolas, S. Willcock, C. Shackleton, C.A. Harvey, and D. Kafumbata. 2016. 'Participatory Data Collection for Ecosystem Services Research: A Practitioner's Manual.' ESPA Working Paper Series 3.

Scoones, I., A. Stirling, D. Abrol, J. Atela, and L. Charli-Joseph. 2018. 'Transformations to Sustainability.' STEPS Working Paper 104. Brighton: STEPS Centre.

Sieber, S.S., P.M. Medeiros, and U.P. Albuquerque. 2011. 'Local Perception of Environmental Change in a Semi-Arid Area of Northeast Brazil: A New Approach for the Use of Participatory Methods at the Level of Family Units.' Journal of Agricultural and Environmental Ethics 24(5): 511-531.

Sinare, H., L.J. Gordon, and E. Enfors-Kautsky. 2016. 'Assessment of Ecosystem Services and Benefits in Village Landscapes - A Case Study from Burkina Faso.' Ecosystem Services 21: 141-152.

Smith, B.M., P. Chakrabarti, A. Chatterjee, S. Chatterjee, U.K. Dey, L.V. Dicks, B. Giri, S. Laha, R.K. Majhi, and P. Basu. 2017. 'Collating and Validating Indigenous and Local Knowledge to Apply Multiple Knowledge Systems to an Environmental Challenge: A Case-Study of Pollinators in India.' Biological Conservation 211: 20-28.

Stirling, A. 2008. 'Opening Up and Closing Down.' Science, Technology, and Human Values 33(2): 262-294.

Stringer, L.C., A.J. Dougill, E. Fraser, K. Hubacek, C. Prell, and M.S. Reed. 2006. 'Unpacking “Participation" in the Adaptive Management of Social-Ecological Systems: A Critical Review.' Ecology and Society 11(2): 39.

Sylvester, O., A.G. Segura, and I.J. Davidson-Hunt. 2016. 'Wild Food Harvesting and Access by Household and Generation in the Talamanca Bribri Indigenous Territory, Costa Rica.' Human Ecology 44(4): 449-461.

Tengö, M., E.S. Brondizio, T. Elmqvist, P. Malmer, and M. Spierenburg. 2014. 'Connecting Diverse Knowledge Systems for Enhanced Ecosystem Governance: The Multiple Evidence Base Approach.’ Ambio 43(5): 579-591. 
Tengö, M., R. Hill, P. Malmer, C.M. Raymond, M. Spierenburg, F. Danielsen, T. Elmqvist, and C. Folke. 2017. 'Weaving Knowledge Systems in IPBES, CBD and Beyond - Lessons Learned for Sustainability.' Current Opinion in Environmental Sustainability 26-27: 17-25.

Tengö, M., P. Malmer, P. Borraz, C. Cariño, J. Cariño, T. Gonzales, J. Ishizawa et al. 2012. Dialogue Workshop on Knowledge for the 21st Century: Indigenous Knowledge, Traditional Knowledge, Science and Connecting Diverse Knowledge Systems. Usdub, Guna Yala, Panama, 10-13 April 2012. Workshop Report. Stockholm: Stockholm Resilience Centre.

Van der Riet, M., and M. Boettiger. 2009. 'Shifting Research Dynamics: Addressing Power and Maximising Participation through Participatory Research Techniques in Participatory Research.' South African Journal of Psychology 39(1): 1-18.

Villamor, G.B., I. Palomo, C.A.L. Santiago, E. Oteros-Rozas, and J. Hill. 2014. 'Assessing Stakeholders' Perceptions and Values towards Social-Ecological Systems Using Participatory Methods.' Ecological Processes 3(1): 22.

Walker, G. 2012. 'Climate Change Oppression: Media Production as the Practice of Freedom.' The Journal of Sustainable Development 9(1): 97-106.

Wang, C., and M.A. Burris. 1994. 'Empowerment through Photo Novella: Portraits of Participation.' Health Education and Behaviour 21: 171-186.

Wang, C., and M.A. Burris. 1997. 'Photovoice: Concept, Methodology, and Use for Participatory Needs Assessment.' Health, Education and Behaviour 24(3): 369-386.

Watts, S., and P. Stenner. 2012. Doing Q Methodological Research: Theory, Method and Interpretation. London: Sage.

West, S., R. Cairns, and L. Schultz. 2016. 'What Constitutes a Successful Biodiversity Corridor? A Q-study in the Cape Floristic Region, South Africa.' Biological Conservation 198: 183-192.

Weyer, D., J. Bezerra, and A. de Vos. 2019. 'Participatory Mapping in a Developing Country Context: Lessons from South Africa.' Land 8(9): 134.

Williams, T., and P. Hardison. 2013. 'Culture, Law, Risk and Governance: Contexts of Traditional Knowledge in Climate Change Adaptation.' Climatic Change 120(3): 531-544. 